Izvorni znanstveni rad

DOI: $10.17234 /$ Croatica.63.5

UDK: $811.163 .42 ’ 366.5$

$811.163 .42 ’ 366.53$

$811.163 .42 ’ 37$

Primljen: 4. II. 2019.

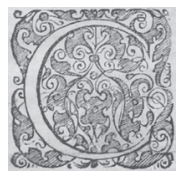

Prihvaćen: 12. IV. 2019.

\title{
GRAMATIČKA VIŠEZNAČNOST KATEGORIJE BROJA
}

\author{
Branka Tafra \\ Sveučilište u Zagrebu \\ branka.tafra47@gmail.com
}

Središnja je tema ovoga rada gramatička višeznačnost kategorije broja, utvrđivanje njezinih osnovnih tipova te otkrivanje asimetričnosti njezinih gramema, osobito u terminološkim sustavima, koja nije uočena i valjano opisana u hrvatskim jezičnim priručnicima. Budući da je odnos kategorije brojivosti u imenica i kategorije broja čvrsto isprepleten da bi se mogao potpuno zaobići, bit će riječi i o njem s osvrtom na kroatističku literaturu i na neka sporna mišljenja. Predložit će se nekoliko dopuna u nazivlju i u tumačenju kategorije broja radi poboljšanja ne samo gramatičkih opisa nego i gramatičke obrade natuknica $u$ rječnicima, u kojima se jasnije ogleda nerazdvojivost gramatike i semantike upravo na primjeru kategorije broja.

Ključne riječi: gramatika, semantika, kategorija broja, jednina, množina

\section{UVOD}

Gramatičke su kategorije oduvijek privlačile istraživače, ponajviše jezikoslovce, ali i druge, u prvom redu filozofe. U jezicima svijeta kategorija se broja različito ostvaruje, a u hrvatskom jeziku ona se ostvaruje kao dvojčani ${ }^{1}$

1 Opisujući kategoriju broja u mnogim jezicima, Corbett (2000) spominje sustave s različitom konfiguracijom od singulara preko duala, triala, kvadrikala, pa paukala i dr., do plurala, ali i više od plurala. Ostavljamo po strani dvojinu (dual) u hrvatskom o kojoj je dosta pisano. 
odnos jednine i množine. Premda se na prvi pogled čini da je vrlo jednostavno ${ }^{2}$ odrediti je li oblik promjenjive riječi u jednini ili množini, to nije uvijek lako ${ }^{3}$ jer postoji velik broj imenica, zadržimo se samo na njima, ${ }^{4}$ za koje nismo sigurni imaju li oba gramema, a ponekad postoji dvojba je li imenica u jednini ili množini pa se tek u kombinaciji s kategorijom roda mogu odrediti oba podatka, npr. kojega su roda i broja imenice babinje, jetra, Sali. Pitanje je može li se uopće o gramatičkim kategorijama, a u članku će biti riječi o kategoriji broja, govoriti izvan konteksta samo na razini izraza. Djelomice može. Ako se o kategoriji broja u imenica govori isključivo o oblicima za jedninu i množinu, onda smo na razini morfologije i shvaćanja kategorije broja kao morfološke kategorije. Ako se objašnjava brojevna asimetričnost imenskoga predikata i subjekta, primjerice zašto imenici većina kao subjektu mjesto otvara predikat jednom u jednini, što je očekivano jer je većina jednina (Većina je došla), a drugi put u množini, što je neočekivano jer je subjekt u jednini (Većina su topola dvodomne vrste), ${ }^{5}$ tada se kategorija broja shvaća kao morfosintaktička kategorija. Morfologija ne može objasniti zašto prilog malo jednom otvara mjesto genitivu jednine (malo sira), drugi put genitivu množine (malo studenata), a treći put i jednomu i drugomu genitivu, ovisno o značenju (malo vína, malo vína $)^{6}$. Ako pak treba objasniti sintagmu jedne hlače, gramatika određuje da je imenica plurale tantum, ali ne može bez pomoći semantike odrediti što je, osim da je kvantifikator, riječ jedne, odnosno kojoj vrsti riječi ona pripada, premda se na prvi pogled čini da je to pitanje isključivo u domeni gramatike. ${ }^{7}$ Prema tomu kategorija broja nema samo svoje morfološke (Znika 2002: 67) označivače nego ima i sintaktičke, ali i rječotvorne označivače. No za potpuno razumijevanje kategorije broja potrebno je izići iz gramatičkih okvira pa uzeti u obzir i leksičko i referencijalno značenje, a ponekad i situacijski kontekst.

2 Corbett (2000: 1) primjećuje da je ta jednostavnost varljiva i da je kategorija broja raznolikija nego što su toga jezikoslovci svjesni.

3 Dokazuju to Babić i sur. (1991) koji sklanjaju (!) ime Nives u jednini i u množini (!), i tako odstupaju od pravila da su imena nebrojive imenice (broje se nositelji imena, a ne imena) koje upravo po onome što znače ne mogu imati opreku jednina - množina.

4 Kategorija broja u drugih vrsta promjenjivih riječi, ali i u frazemima (dječja igra - dječje bolesti, crna ovca - crne misli, ali imati pun džep/džepove), zasebna je tema.

5 Takvi se primjeri mogu naći u tekstovima, npr. Manji dio neofita su invazivne vrste.

6 Treba razlikovati značenje imenice vino u ovim dvjema rečenicama: Popio je malo vína i Malo je vínā, pogotovo slavonskih. V. poglavlje 3.3.

7 Literatura različito gleda na taj problem. V. Tafra 2005: 13. 
Polazimo stoga od stajališta da su gramatika i semantika nerazdvojive te da zapravo i ne postoji neka čvrsta granica između gramatičkih i semantičkih kategorija, a da se ona uzima samo radi lakšega opisa. To ne znači da se jezične razine bez razloga mogu miješati, kao što se sreće u literaturi $\mathrm{u}$ kojoj nije rijetkost da se u formalni morfološki opis uvode sintaktičke ili pak semantičke kategorije. Gramatičke su kategorije promjenjivih riječi u uskoj vezi s funkcijom tih riječi i njihovim značenjem, samo se u opisima mijenja pristup, jednom je on više morfološki, drugi put funkcionalni, a treći put semantički. Manje-više sve je to poznato, a ovdje je spomenuto samo zato da se vide polazišta na kojima se temelji ovaj rad.

Kategorija je broja u jezikoslovnoj literaturi često bila temom proučavanja $^{8}$ pa cilj ovoga rada nije da obuhvati svu problematiku te kategorije, ali ni da dade pregled literature o njoj. S obzirom na to da je tema preopširna za članak manjega opsega, više se podataka i tumačenja može naći u ostaloj literaturi, a u ovom ćemo se radu uglavnom baviti višeznačnošću kategorije broja i asimetričnošću njezinih gramema. Nećemo ulaziti dublje u problem razgraničenja i preklapanja kategorije broja i kategorije brojivosti jer je to tema sama za sebe, ali se mora i ona načeti jer je odnos th kategorija suviše isprepleten da bi se mogao potpuno zaobići. Osvrnut ćemo se na neka mišljenja u kroatističkoj literaturi, pogotovo na ona s kojima se ne slažemo, ${ }^{9}$ dotaknut ćemo se teorijskih pitanja, osvrnut ćemo se i na nazivlje te predložiti nekoliko dopuna, a primjerima iz terminoloških sustava proširiti spoznaje o kategoriji broja, koje svoju primjenu, osim u gramatičkim opisima, svakako trebaju naći mjesto i u rječnicima koji su prikladniji za opis pojedinih imenica u kojima se jasno ogleda nerazdvojivost gramatike i semantike upravo na primjeru kategorije broja.

8 Ovo je nastavak dosadašnjega autoričina bavljenja njome, doduše uvijek u širem kontekstu uz druge teme (Tafra 2000a, 2000b, 2007, 2017).

9 Već je dosad bilo pisano o nedopustivim pogrešnim primjerima određivanja kategorije roda i broja u temeljnim hrvatskim jezičnim priručnicima u kojima su, među ostalim, vrata, leđa ženskoga roda (dakle jednina), a kola, leđa jednina (Tafra 2007). 


\section{KROATISTIČKI POGLED}

Broj i rod uz padež su prve gramatičke kategorije koje se uče u školi. Međutim, hrvatske gramatike i rječnici pružaju iskrivljenu sliku tih kategorija ${ }^{10}$ kao što je vidljivo u Hrvatskoj školskoj gramatici (Hudeček i Mihaljević 2017: 31) koja osnovnoškolce zaista može zbuniti proglašavajući imenice razred, stado, narod imenicama singularia tantum, pogotovo što iste autorice uz te imenice u Školskom rječniku (ŠRHJ) stavljaju množinske oblike, što je ispravno. ${ }^{11}$ Ako se tomu doda da se kao primjer za zbirne imenice u jednini uzima imenica momčad (Naša je momčad pobijedila), koja je upravo rijetka imenica na sufiks - ad koja ima oba gramema, a za množinu se navode djeca i braća, jasno je da učenici na početku svoga školovanja ne svladaju osnovne podatke o kategoriji broja.

Različitost gledišta i nesuglasje u temeljnim polazištima u domaćoj jezikoslovnoj literaturi dobro ilustriraju dvije knjige nastale na osnovi doktorskih radova: Kategorija brojivosti u hrvatskom jeziku (Znika 2002) i Oblici nebrojivosti u hrvatskom jeziku (Peti 2004). ${ }^{12}$ Iako su to knjige o kategoriji (ne)brojivosti, u njima je nezaobilazna tema i kategorija broja. Očekivalo bi se da nema razilaženja u shvaćanju što je jednina, a što množina, ali se ni u tome dvoje autora nije složilo. Za Zniku jedninu i množinu imaju samo brojive imenice, odnosno one su njezin izraz na morfološkom planu, dok su za Petija (2004: 21) brojivost i nebrojivost ,semantička obilježja gramatičke kategorije broja, izvedena iz te kategorije is njom modelski nerazdvojno povezana". Znika polazi od brojivosti prema broju, a Peti obratno, od broja prema brojivosti.

Silić i Pranjković (2005: 38) imaju samo jednu rečenicu o kategoriji broja: „Kategorije broja [sic!]. One razlikuju jedninu i množinu (üčenīk- $\varnothing$ - üčenīc-i)." O brojivosti se posebno ne govori, ali se spominje brojiva i nebrojiva množina (isto: 239) te zbirna množina (isto: 297). U odjeljku o sročnosti po broju (isto: 239) objašnjava se da ,zbirne imenice nemaju zapravo ni obilježja jednine ni obilježja množine, nego su rezultat svojevrsne neutralizacije opreke po broju". Pranjković je i prije (1984: 175) napisao da morfemski izražena ,zbirna množina ipak nije 'prava' množina (nego

10 Istinitost te tvrdnje pokazala je analiza mnogih primjera upravo iz gramatika i rječnika te analiza provedene ankete (Tafra 2007). Ovdje ćemo naglasak dati više na kategoriju broja, iako smatramo da ju je najbolje promatrati zajedno s kategorijom roda, barem u školskoj praksi.

11 Dobar bi rječnik trebao staviti odrednicu sg. $t$. u obradi višeznačnice narod uz značenje 'mnoštvo ljudi', a u obradi natuknice razred uz značenje 'oznaka stupnja putničke udobnosti' (putnik prvoga razreda) jer imenice narod i razred u većini svojih značenja imaju oba gramema.

12 Prilično oprečna gledišta nisu bila zaprekom da autori prihvate uredničku ulogu jedno drugomu. 
neki tip neutralizacije po broju, nekakva 'množinska jednina' ili 'jedninska množina')". Međutim, teško bi bilo dokazati da imenica telad nije jednina ženskoga roda. Dakle, zbirne imenice djeca, braća, gospoda i vlastela jesu imenice ženskoga roda u jednini i zato ne treba reći da se „sklanjaju kao [podvukla B. T.] imenice ženskoga roda u jednini”, ni da se imenice tipa paščad, guščad, telad, unučad, čeljad i sl.” [...] ,,ponašaju kao imenice ženskoga roda u jednini” (Silić i Pranjković 2005: 298) jer one to jesu. Ni Hrvatska gramatika (Barić i sur. 1995: 237) u opisu imeničnih kategorija nema nešto više o kategoriji broja, spominje tek imenice pluralia tantum, a singularia tantum i ne spominje, iako se naziv nalazi u kazalu.

Osim što uza svaku sklonidbenu vrstu ima primjere za singularia i pluralia tantum, Marković (2012) donosi iz literature zanimljivosti o kategoriji broja u jezicima svijeta.

O odstupanjima u ostvaraju imeničnih kategorija i o tome kako ih jezični priručnici opisuju bilo je riječi u radu ,Nepravilnici” ${ }^{13}$ u hrvatskoj gramatici i rječniku (Tafra 2000a). U njem je dana osnova za tipologiju netipičnih primjera, otvorena za doradu, pa je tako za kategoriju broja utvrđeno devet skupina imenica koje imaju samo jedninu, četiri skupine imenica koje imaju samo množinu, tri skupine imenica singularia tantum koje se mogu pluralizirati, zatim skupina brojivih imenica koje se, najčešće iz stilskih razloga, u određenim kontekstima singulariziraju, skupina brojivih imenica koje uz množinu motiviraju i tvorbu zbirnih imenica, skupina zbirnih imenica koje imaju množinu te na kraju potpuni sinkretizam (i jd. i mn.).

Pojedinačnih se podataka nađe i u ostaloj jezikoslovnoj literaturi, pa i u medijima u kojima kroatisti često daju savjete. Tako su se u radijskoj emisiji mogli čuti jezični savjeti da u meteorološkim izvještajima sinoptičari trebaju voditi računa je li jedna ili je više oborina i da je oblik medovi ispravan. ${ }^{14}$ Zar zaista danas u Hrvatskoj pada pet oborina i zar se može kupiti pet medova?

Propusti se u opisu kategorije broja u hrvatskoj jezikoslovnoj literaturi, osobito u rječnicima i gramatikama, mogu sažeti u nekoliko točaka:

1. Ne razlikuje se što je jedna, a što su dvije riječi, odnosno ne razlikuje se što je tvorba riječi, a što fleksija, pa se dvije riječi stavljaju u odnos jednine i množine kao da su jedna riječ.

3 Naziv „nepravilnici” preuzet je od Adolfa Vebera.

14 Odgovor na komentar slušateljice kojoj smeta jednina naziva oborina u meteorološkim izvještajima jer ona smatra da su dvije, tri, pet oborina, iz svakoga oblaka jedna. Radio Sljeme, Hrvatski naš svagdašnji, 22. 10. 2018. Medovi su bili na istom mjestu 26. 11. 2018. i nije bilo ni riječi o tvarnim imenicama koje nemaju množinu u svom osnovnom značenju. 
Nije rijetkost da se u zadacima za učenike, ali i u jezikoslovnoj literaturi imenice brat i braća, dijete i djeca, unuče i unučad smatraju jedninskim i množinskim oblikom jedne riječi te se pritom griješi i pri određivanju roda. Tako je istraživanje udžbenikâ pokazalo da se uspostavlja isti odnos između primjera oko - oči, uho - uši i dijete - djeca, brat - braća te se tako na početku učenja o kategoriji broja stječe pogrešno znanje o njoj, što se i potvrdilo anketom u kojoj 100 \% srednjoškolskih profesora hrvatskoga jezika i studenata kroatistike prve godine imenicu djeca smatra množinom. Uz to većina ih drži da je to imenica srednjega roda (Tafra 2007).

Jednako prolazi i imenica braća. Čak i Marković (2012: 307) smatra da su dvije riječi brat i braća zapravo oblici jedne riječi: „Ako pretpostavimo da brat i braća stoje u odnosu singular - plural, odnosno da je riječ o leksemu BRAT, onda imamo ovo: moj-ø brat-ø (MASC. SG.), moj-a brać-a (FEM. SG.), moj-a brać-a su oženjen-a (NEUT. PL.). Dakle doista zanimljiv leksem koji može biti triju rodova i dvaju brojeva." Nejasno je kako dvije imenice koje su singularia tantum mogu stajati u odnosu jednine i množine, a osim toga upravo posvojna zamjenica dokazuje da su brat i braća dvije riječi i da su moja braća u oba primjera ženski rod bez obzira na predikatnu sročnost.

2. Semantičkim se kategorijama pristupa iz morfološkoga očišta pa se one često izmiješaju tako da se jednina proglašava množinom jer imenica označuje skupnost istovrsnih entiteta.

Semantičke kategorije imaju svoje morfološke i sintaktičke obilježivače te je nemali njihov utjecaj na kategoriju broja, npr. konkretne imenice uglavnom imaju potpunu paradigmu, oba gramema, dok apstraktne imaju asimetričnu paradigmu. Međutim, u upotrebi tih imenica ima i obrata pa se brojive upotrebljavaju kao nebrojive, a nebrojive kao brojive. ${ }^{15}$ Najčešće se griješi sa zbirnim imenicama jer se zbirnost ne shvaća kao semantička kategorija, nego se opisuje u morfologiji jer neke od njih imaju tvorbene označivače (imenice sa sufiksom - $a d,-j e,-s t v o,-e z ̌$ itd.). Pri tom se miješaju njihovo leksičko značenje mnoštva i gramatičko značenje jednine. Zbirne su imenice općenito, a osobito one sa sufiksom -ad te one tipa djeca i braća, slaba karika hrvatskoga jezikoslovlja. U rječnicima je gramatička odrednica za zbirnost suvišna jer se ne označuju ni druge semantičke kategorije (apstraktnost, konkretnost ...), a osim toga iz definicije je vidljiva zbirnost (,skup [...]"). Izostanak pak odrednice za rod uz zbirne imenice, kao što je u Anića (djeca zb. od dijete, braća zb. od brat), ujedno je i izostanak podatka o broju jer se tako ne razgraničuju gramatička obilježja imenicâ usta i djeca

15 Više o tome u Belaj i Tanacković Faletar 2014. 
koje su oblikom izjednačene. Još je gore kad se uz imenice brat i dijete stavi u zoni gramatičkih podataka u rječničkom članku ,zb. braća" i ,zb. djeca” jer uporabnik rječnika neće shvatiti razliku između zbirnosti i množine. Rješenje je vrlo jednostavno, samo treba zbirne, apstraktne, tvarne ... imenice smjestiti na istu razinu kao podrazrede leksičko-gramatičkoga razreda imenica.

3. Ne prepoznaje se asimetričnost kategorije broja u imenica singularia tantum zbog semantičke zapreke, a u imenica pluralia tantum zbog morfološke zapreke. Otuda određivanje imenica tipa dvojica množinom, a vrata jedninom (Tafra 2007).

4. Ne prepoznaje se višeznačnost kategorije broja.

Gramatička je višeznačnost slična leksičkoj jer višeznačna riječ može u jednom značenju imati oba gramema kategorije broja, a u drugom samo jedan pa dakle takva riječ ima dva leksička i dva gramatička značenja. Tako vrijeme kao meteorološki ili gramatički naziv nema množinu, ali u drugim značenjima (npr. 'uvjeti života') ima.

5. Ne prepoznaje se rod imenice pa se otuda ne prepoznaje ni broj.

Imenice tipa djeca zbog značenja, ali i zbog različita atributnoga i predikatnoga slaganja ne prepoznaju se kao imenice ženskoga roda jednine. Iako se semantika i gramatika isprepleću, treba znati lučiti formalni (morfološki) opis od opisa značenja, a upravo se u tom slučaju u kroatističkoj literaturi nažalost često griješi. Manje bi se griješilo ako bi se u gramatikama u poglavljima o morfologiji opis kategorije broja vezao uz ispravno tumačenje kategorije roda određujući ga sintaktičkim kriterijem (ova žena, ova djeca) i ako se zbirne imenice ne bi proglašavale množinom od imenica iz skupine singularia tantum.

\section{TEORIJSKI POGLED}

Kategorija broja u imenica ima ove morfološke označivače:

1. potpuna paradigma

2. nepotpuna paradigma

a. singularia tantum

b. pluralia tantum

3. nepotpuna i potpuna paradigma

4. sinkretizam padeža i broja. ${ }^{16}$

16 Obuhvaća nepromjenjive riječi. U hrvatskom su to neke posuđenice te doba i podne (te dvije imenice mogu biti i promjenjive). One nemaju morfološke označivače jednine i množine, ali imaju sintaktičke (ovo doba, ova doba). 
Tablica 1: Morfološki označivači kategorije broja

\begin{tabular}{|l|c|c|}
\hline imenica & jednina & množina \\
\hline ormar & + & + \\
\hline ozon & + & $\varnothing$ \\
\hline sanjke & $\varnothing$ & $\varnothing$ \\
\hline ulje 1. tvar ${ }^{17}$ & + & + \\
2. a) vrsta te tvari & + & + \\
b) pakovanje te tvari & + & $\varnothing$ \\
\hline doba & $\varnothing$ & + \\
\hline
\end{tabular}

Uključujući i leksičku semantiku, otkriva se da ista imenica može istodbno pripadati dvjema skupinama, a to pak dokazuje da je i kategorija broja također višeznačna (Tafra 2017).

\subsection{Nazivlje}

Za shvaćanje kategorije broja potrebno je razumjeti što je jedno i što nije jedno u jeziku i izvan jezika. Pritom je važno svaki pojam valjano imenovati. Primjerice, u vezi s naslovom ovoga rada treba reći da su u sintagmi kategorija broja obje imenice nebrojive i da nemaju množinu. ${ }^{18}$ Kategorija broja ima dva gramema: jedninu i množinu. Budući da su to gramatički nazivi, uz njih ne treba atribut gramatički. Naime, često se u literaturi spominje semantička množina pa bi po logici stvari trebala biti i gramatička množina. U gramatici je također suvišan naziv zbirna množina jer imenice tipa telad u morfologiji su jednina i svrstavaju se u skupinu imenica ženskoga roda s nultim nastavkom koje se sklanjaju po sklonidbi $i$, a značenje mnoštva pripada leksičkoj semantici. Suvišan je i naziv zbrojina (Peti 2001) kao posebna oznaka kategorije broja koja bi obuhvaćala tako različite imenice kao što su družina, lišće, telad, studenti, svatovi, Hrvati i sl. (Peti 2001: 210). Premda kategorija zbirnosti ,ima svoja i semantička, i sintaktička i morfološka obilježja koja dio imenica izdvaja od drugih" (Tafra 2000a: 75), ona na kategoriju broja utječe tako da većina tih imenica nema množinu pa se one svrstavaju u singularia tantum (npr. djeca, braća, gospoda, telad ...).

17 Nadređenica zamjenjuje definiciju. Drugo značenje obuhvaća vrstu po kvaliteti (maslinovo, sojino...) ili po zemljopisnom porijeklu (dalmatinsko, istarsko, grčko...).

18 Jedna je kategorija koja se može različito ostvarivati. Stoga je naslov doktorskoga rada trebao biti u jednini, a ne u množini: Tatjana Pišković. 2010. Kategorije roda u hrvatskome standardnom jeziku (gramatička, leksička, referencijalna i društvena). Doktorski rad. Zagreb: Filozofski fakultet Sveučilišta u Zagrebu. 
Gramatički odnos polje - polja ne može biti jednak odnosu dijete - djeca jer je u prvom primjeru jedna riječ, a u drugom su dvije. Taj je odnos usporediv samo na značenjskoj razini, ali nije i na morfološkoj. Naime, kategorija broja ima morfološke označivače (Corbett 2000), u hrvatskom su to jednina i množina, a zbirnost (Petijeva zbrojina), odnosno kolektiv (u više autora) nije treći ${ }^{19}$ označivač, nego je obilježje značenjske strukture imenice. Primjeri tipa petero prognanika nisu dokaz nove oznake kategorije broja u kojoj su neutralizirani jednina i množina, kako smatra Peti (2001: 218), jer je genitiv množine morfološki označivač množine. Razlikovanje pet studenata kao množine nasuprot petero studenata kao zbrojine (Peti 2001: 221) i tumačenje da je riječ o dvjema imeničnim paradigmama nema nikakva uporišta $u$ gramatici jer je imenica u oba primjera u genitivu množine. Ni tvrdnja da pet studenata označava izbrojenu količinu, a u petero studenata samo zbroj nije točna jer svi brojevi, a petero jest broj, označavaju izbrojenu količinu. Postoji samo značenjska razlika, u prvom je primjeru glavni broj uz imenicu muškoga roda koja znači neko zanimanje neutralizirao spol referenta, dok u drugom zbirni broj otkriva da imenica označuje i muške i ženske osobe. Premda značenje imenice uvelike utječe na kategoriju broja, ne bi se smjele miješati razine jer je činjenica da su zbirne imenice (djeca, telad, lišće ...), bez obzira na njihovo značenje, u jednini, a izuzetno imaju i množinu (momčadi).

\subsection{Broj i brojivost}

Pravu sliku složenoga odnosa broja i brojivosti može se dobiti jedino u kontekstu. U 2. poglavlju već je bilo nešto riječi o tom odnosu, a ovdje mu se vraćamo kako bismo pokazali primjere višeznačnosti kategorije broja koja ovisi o kategoriji brojivosti.

Obično se kaže da samo brojive imenice imaju oba gramema, odnosno da „brojivost ima svoj izraz na morfološkom planu u gramatičkoj kategoriji broja, njezinim gramemima jednini i množini” (Znika 2002: 67). Odnos je tih dviju kategorija tako pojednostavljen pa izlazi da brojive imenice imaju jedninu i množinu, tj. da su imenice s potpunom paradigmom broja brojive te se iz toga i ne vidi koja je razlika između tih dviju kategorija, a i ne vidi se da samo kontekst može otkriti je li imenica brojiva ili nebrojiva. Odnos tih dviju kategorija mnogo je složeniji jer ni granica između brojivih i nebrojivih imenica nije uvijek jasna. Tako brojive imenice mogu biti i

19 Prije bi to bila dvojina (dva gradska projekta) s obzirom na oblik pridjeva. 
imenice koje uopće nemaju jedninske i množinske oblike, odnosno koje nemaju morfološke označivače broja, ali imaju sintaktičke, koje se obično nazivaju nepromjenjive. Brojive mogu biti i neke imenice pluralia tantum, ali i dio imenica singularia tantum koje se u svom sekundarnom značenju pluraliziraju jer se ono opredmetilo, dok nebrojive mogu pak biti imenice koje imaju oba gramema. Prelazak brojivih u nebrojive imenice (Zec rado jede mrkvu), ali i nebrojivih u brojive (Sjetio se svih svojih ljubavi), događa se često u kontekstu ovisno o tome konceptualiziraju li se imenice primjerice kao tvarne ili se metaforizacijom opredmećuju. Ako je ono što imenica znači odvojivo, razlučivo, imenica je brojiva. Iz kroatističke ${ }^{20}$ bi se literature dalo zaključiti da samo konkretne imenice (apstraktne su označene kao nebrojive, kao singularia tantum) mogu biti brojive, no i one mogu biti nebrojive, iako nisu ni tvarne ni zbirne (obje su skupine singularia tantum), npr. momče, djevojče, brat itd. Množinski oblik snjegovi u Hemingwayevim Snjegovima Kilimandžara nije vrsta oborine nego znači 'veliko snježno prostranstvo' ili 'velika količina snijega' i ne može se tvrditi da je snijeg brojiva imenica samo zato što ima potvrdu za množinu. Snijeg je i dalje kao meteorološki naziv nebrojiva imenica, ali je brojiva u drugom značenju. Činjenica je da se sve više apstraktnih imenica koje pripadaju skupini singularia tantum pluralizira i da se takva njihova upotreba ne može uvijek smatrati kršenjem normi. Nije svaki put riječ o konkretizaciji značenja, kao uvjetu za brojivost, npr. imenica nacionalizam ostaje apstraktna imenica i kad se upotrijebe množinski oblici, npr. Države-nacije i nacionalizmi (naslov knjige). Hoće li u nekim kontekstima ta imenica imati značenje 'vrsta' (npr. mađarski i poljski nacionalizam dvije su vrste nacionalizma), treba provjeriti u svakom kontekstu. Načelno za provjeru brojivosti mogu, u prvom redu u školskoj praksi, poslužiti brojevi veći od četiri (*pet djeteta, ali pet ormara) i brojevni pridjevi ${ }^{21}$ (jedni, dvoji svatovi) za pluralia tantum, što je pouzdanije nego utvrđivanje je li imenica apstraktna ili konkretna. Iako matematička i jezična izbrojivost nisu isto, iako se brojive imenice ne moraju kvantificirati brojevnim riječima da bi bile brojive (npr. *pet bolova, ali nesnosni bolovi), u većini će slučajeva upravo brojevne riječi pomoći u rješavanju dvojbi što je brojivo, a što nije. U ruskom posuđenice obično ne dobivaju nastavke

20 Prostor nam ne dopušta da se osvrnemo i na opise u drugim jezicima.

21 Uz te se imenice uvrštava pridjev, a ne broj, kako Znika (2002: 132) tvrdi: „Imenice [su] pluralia tantum s oznakom [- apstraktno] - tipa grablje, hlače - brojive, pa se uz njih, kao i uz druge brojive imenice, može uvrstiti broj." 
pa bi po kroatističkoj literaturi to bile nebrojive imenice. Budući da se u ruskom može reći один польто і сто польто, ili u češkom pět kupé, iako te imenice zbog nepromjenjivosti nemaju morfološke označivače jednine i množine, one su brojive, što u kontekstu pokazuju ne samo kvantifikatori nego i determinatori (podvukla B. T.):

Много хлопот доставляют старые пальто, висящие в шкафах или убранные на антресоли. Такое пальто может послужить материалом для пледа или...22

U ruskom, kao i u hrvatskom „несклоняемыми сущ-ими называются слова, имеющие во всех употреблениях только одну форму, в которую заключены разные числовые и падежные значения: кашне, какао, рагу, метро. Такие слова не имеют окончаний и выражают значения рода, одушевленности - неодушевленности, числа, падежа только синтаксически...” (Ruska gramatika 2002: 200).

Da bi se ispravno odredilo koje imenice imaju oba gramema, a koje zbog značenjskih zapreka nemaju, potrebno je razumjeti narav odnosa jednine i množine kao jednoga od načina kvantifikacije u jeziku (Šarić 2002). Tvrdnja da „u gramatičkoj kategoriji broja bitna je jezična opreka jedno $\neq$ više no jedno, mnogo, u temelju koje leži značenjska opreka jediničnost $\neq$ mnogost" (Znika 2002: 75) prilično je sporna jer je naziv jediničnost, koja se može shvatiti kao razlučivost entiteta $(1+1+1 \ldots)$, prikladan za brojive imenice, a kategorija broja obuhvaća i brojive i nebrojive imenice, dok se pak naziv mnogost odnosi i na zbirne imenice (koje su singularia tantum) i na množinu.

Naime, jedno u zbilji ne znači jedninu u jeziku (npr. leđa, vrata, osti, škare), a mnogo ne znači u jeziku množinu (npr. djeca, braća, narod), a ni „više no jedno" ne znači uvijek množinu. Primjeri dva brata i tri grada nisu u tom obliku primjeri za množinu, iako im značenje obuhvaća „više no jedno” te iako te oblike Pranjković (2013: 129) naziva „malom množinom" u odnosu na „veliku množinu”. Kako god tumačili oblik grada u sintagmi tri grada, morfološki on nije na drugoj strani odnosa na kojem se temelji kategorija broja: grad - gradovi. „Više no jedno” vrijedi kao množina za parove: oči, uši, rukavice, cipele... i nije sinonimno s mnogo jer mnogo „označuje veliku količinu ili mjeru" (ŠRHJ). Da bi se značenjski odnos nasuprot gramatičkomu

22 http://ledaforum.4bb.ru/viewtopic.php?id=878 (Клуб домашних швей | Форум; pristupljeno 6. 9. 2018). 
jednina - množina točnije imenovao, pogotovo što je mnogo u opreci s malo, predlažemo jednobroj-višebroj ${ }^{23} \mathrm{u}$ skladu sa sličnim oprečnim nazivima: jednočlan - višečlan, jednoglasje - višseglasje, jednojezičnost - višejezičnost itd. Dakle, jednina može imati značenje i jednobroja (knjiga) i višebroja (braća), a množina može imati značenje i višebroja (knjige) i jednobroja (pluća), ovisno o tome označuje li jedan entitet ili više entiteta. Kategorijalni se prijelazi iz nebrojivoga u brojivo događaju pri semantičkoj derivaciji od apstraktnoga prema konkretnomu značenju, od primarnoga prema sekundarnomu značenju, pri metonimijskom i metaforičkom razvoju značenja, ali i pri prijenosu naziva s hiperonima na hiponim i rjeđe obratno, osobito „у зоолошкој и ботаничкој класификацији и таксонимији”, što se inače događa u europskim jezicima uopće (Gortan-Premk 1997: 83). Semantička se derivacija gramema može istraživati istim metodama kao i semantička derivacija polisemnih leksema.

\subsection{Ostvaraji kategorije broja}

Iako je već bilo riječi o kategoriji broja u kontekstu, vidjet ćemo još neprototipnih njezinih ostvaraja koji su ostali izvan kroatističkih gramatičkih i rječničkih opisa. Ako se kategorija broja ostvaruje u svojoj potpunosti, ima, kako je već rečeno, dva gramema: jedninu i množinu, a ako se ostvaruje samo jedan gramem, riječ je o nepotpunoj paradigmi, odnosno o asimetričnosti. Vidjeli smo da je Veber u 19. stoljeću promjenjive riječi s nepotpunim paradigmama nazivao nepravilnicima. To je sasvim dobar naziv jer su njime obuhvaćene promjenjive riječi koje odstupaju od oblikotvornih pravila. U literaturi se danas u mnogim europskim jezicima, pa tako i u hrvatskom pod utjecajem latinske gramatike takve riječi obično nazivaju defektivi, defektivne/defektne imenice, glagoli itd. (Pišković 2011, Marković 2012), a nerijetko i jezičnom anomalijom (Znika 2002). Prazna polja u sklopu paradigme Plungjan (2016: 104) naziva „,defektivnost paradigme”. Imenice ormar, knjiga i selo tipični su predstavnici sklonjivih imenica koje imaju potpunu paradigmu kategorije broja. Imenice ozon, hlače i Vinkovci netipični su predstavnici jer imaju nepotpunu paradigmu, ${ }^{24}$ dok su imenice vino i ljubav prijelazni jer imaju i potpunu i nepotpunu paradigmu ovisno o značenju.

Ne smatramo da je u realizaciji bilo koje gramatičke kategorija bilo što defektno, pogotovo što defektnost u hrvatskom jeziku ima jako negativno konotativno značenje. Odsutnost ne znači nepostojanje. Objasnit ćemo to na

23 U 19. st. to su bili nazivi za jedninu i množinu.

24 Nepotpune paradigme imaju i druge vrste riječi, npr. u sprezanju glagoli kišiti, valjati i sl. 
jednostavnim primjerima. Kad kažemo da brojevi kao vrsta riječi nemaju kategoriju broja, onda ne postoji nikakva morfološka oznaka za nju, dok kod imenica koje imaju asimetričnu paradigmu, nulta paradigma stoji na mjestu „rezerviranom” za neostvarenu drugu morfološku oznaku. Stoga je neusporedivo nepostojanje kategorije broja u brojeva i jednine u imenica pluralia tantum te množine u imenica singularia tantum. Čim u jeziku postoji simetričnost, asimetričnost razumijeva nulto mjesto. Umjesto anomalije i defektnosti bolje bi bilo govoriti o nultom mocijskom parnjaku, nultom antonimu, nultom naglasnom $z^{n} \mathrm{ku}^{25}$, nultoj sklonidbi ${ }^{26}$, a u ovom slučaju kategorije broja o nultoj paradigmi. Naime, imenice singularia tantum uvijek se mogu pluralizirati, dobiti množinske oblike, a imenice pluralia tantum mogu se, doduše na drugačiji način, singularizirati. One svoju singularnost ne iskazuju morfološkim, nego sintaktičkim obilježivačem: jedne hlače.

Obično se u gramatikama navode leksičke skupine koje nemaju množinu (tvarne, apstraktne...) i, s druge strane, nabrajaju se imenice koje ni formalno ne mogu tvoriti jedninske oblike (npr. sanjke, svatovi, vrata). Međutim, ostala je neuočenost višeznačnosti kategorije broja koju dobro ilustriraju sve tri tablice u ovom radu.

Ovisno o leksičkom značenju, imenica može imati više gramema jednine ili množine, kako pokazuje tablica 2.

Tablica 2: Višeznačnost kategorije broja

\begin{tabular}{|l|c|c|c|c|}
\hline broj & $\begin{array}{c}\text { vino }_{1} \\
\text { 'vrsta' }\end{array}$ & $\begin{array}{c}\text { vino }_{2} \\
\text { 'piće' }\end{array}$ & $\begin{array}{c}\text { cipele }_{1} \\
\text { mn. }\end{array}$ & cipele $_{2}$ 'par' \\
\hline jednina $_{1}$ & + & & + & \\
\hline jednina $_{2}$ & & + & & $(+)$ \\
\hline množina $_{1}$ & + & & + & + \\
\hline množina $_{2}$ & & & & + \\
\hline
\end{tabular}

„Da je riječ o različitoj jednini i množini, dokazuje njihovo slaganje s glavnim brojevima. Uz vino $_{2}{ }^{27}$ ne mogu stajati glavni brojevi, a uz vino ${ }_{1}$

25 Nije riječ o jezičnom znaku, nego o naglasnom znaku za kratkosilazni naglasak u Šime Starčevića (Tafra 2002).

26 Nepromjenjive imenice ne mijenjaju svoj oblik, ali se zapravo mijenjaju po padežima, svaki padežni oblik ima svoje gramatičko značenje, samo im je uvijek jednak izraz pa je riječ o gramatičkoj homonimiji ili o paradigmatskom sinkretizmu. Zato je predloženo da se ta sklonidbena vrsta zove nultom (Tafra 2004).

27 Brojke označuju gramatičku i leksičku višeznačnost, a ne posebne riječi. Usp. $\operatorname{rad} O b a, o b a d v a$ u Tafra 2005. 
i cipele $_{1}$ mogu, dok se cipele $_{2}$ kvantificiraju brojevnim pridjevima" (Tafra 2017: 567-568), a ako se kvantificiraju glavnim brojevima, Belaj i Tanacković Faletar (2014: 89) smatraju da u tom slučaju označavaju rasparene parove, npr. „dvije čarape iz dvaju različitih parova”. No ne moraju biti rasparene (Složi dvije po dvije čarape, dakle u parove), ali se u tom slučaju broje jedinični, a ne parni predmeti. Ako se dalje analiziraju različiti načini nastanka množine, dobit će se sedam tipova množine.

Tablica 3: Tipologija množine

\begin{tabular}{|c|c|c|c|}
\hline jednina & \multicolumn{2}{|c|}{ množina } & napomena \\
\hline ormar & ormari & $\mathrm{mn}_{\cdot 1}$ & morfološki označivači \\
\hline čovjek & ljudi & $\mathrm{mn}_{\cdot 2}$ & leksički označivači \\
\hline$\varnothing$ & sanjke & $\mathrm{mn} \cdot 3$ & primarna im. pl. $t_{\cdot 1}$ \\
\hline $\begin{array}{l}\text { cipela } \\
\text { (cipela) }\end{array}$ & $\begin{array}{l}\text { cipele } \\
\text { cipele 'par' }\end{array}$ & $\begin{array}{l}\mathrm{mn}_{\cdot} \\
\mathrm{mn} \cdot 4\end{array}$ & sekundarna im. pl. $t_{.2}$ \\
\hline $\begin{array}{l}\text { (četinjača; } \\
\text { singulativ) }\end{array}$ & četinjače & $\mathrm{mn} \cdot 5$ & sekundarna im. pl. t.3 \\
\hline oko & $\begin{array}{l}\text { 1. oči } \\
\text { 2. oka }\end{array}$ & $\begin{array}{l}\mathrm{mn} \cdot 4 \\
\mathrm{mn} \cdot 1\end{array}$ & gramatička i leksička višeznačnost množine \\
\hline doba & doba & $\mathrm{mn}_{.6}$ & sinkretizam padeža i broja \\
\hline$\varnothing$ & izbori, pol. & $\mathrm{mn}_{\cdot 7}$ & leksikalizacija množine (nova riječ), $p l . t_{\cdot 4}$ \\
\hline
\end{tabular}

Množina kao gramem kategorije broja koji označuje skup razlučivih entiteta nastaje na različite načine. Da je riječ o različitim tipovima množine, dokazuje i različita mogućnost njezine numeričke kvantifikacije: pet ormara (cipelâ, okâ, doba ${ }^{28}$ ), petero ljudi ${ }^{29}$, petere sanjke (tako i izbori), pet pari cipela/petere cipele (tako i oči), pet vrsta četinjača. Tipologija bi bila još složenija ako bi se uključili i podtipovi kao što su nove riječi nastale konverzijom, npr. nastanak imenice zeleni pl. t. treba tumačiti kao kombinaciju dvaju rječotvornih procesa. Prvi je semantički - leksikalizacija pridjevnoga oblika množine (fleksijski oblik $\rightarrow$ riječ), a drugi je konverzija (pridjev $\rightarrow$ imenica).

Najčešći način nastanka množine jest morfološki (u tablici mn. $\left.{ }_{1}\right)$ jer se na osnovu dodaju množinski nastavci koji su u opreci s jedninskim (ormar-i). Morfološki su označivači množine (množinski nastavci) i u drugim tipovima,

28 Naslov knjige: Pet doba svemira.

29 „Kao biološki naziv imenica ljudi obuhvaća i muške i ženske osobe, te dvoje ljudi znači ‘jedno muško i jedno žensko'. U prošlosti češće, danas više u dijalektima imenica ljudi ima značenje 'muškarci'. Tada su dvojica ljudi' (Tafra 2005: 37). 
ali se u svakom tipu razlikuje njihov odnos prema jednini. Drugi je način nastanka množine leksički: čovjek - ljudi. Iako se čovjek i ljudi mogu smatrati dvjema riječima (u tom bi slučaju ljudi bili plurale tantum), mi taj primjer svrstavamo u supletivizam kao što je primjer dobar-bolji. U tu skupinu ne ulaze zbirne imenice koje nemaju množinsku paradigmu. Imenice pluralia tantum mogu se svrstati u četiri skupine. Prve su primarne, one ni teorijski ne mogu imati jedninske oblike, tip sanjke i Vinkovci. Druge dvije vrste imenica zapravo su sekundarne pluralia tantum jer se upotrebljavaju i kao primarne, ali imaju i jedninske oblike. Odnos cipele (mn. od cipela) i cipele ('par') protumačen je uz tablicu 2, a četinjača i četinjače u poglavlju 4. Razlika je među tim dvama tipovima sekundarnih imenica pluralia tantum što u prvom slučaju postoji i prototipni oblik množine (hrpa cipelâ) i što se upotrebljava i jedninski oblik od para (Probajte i lijevu cipelu), dok se u drugom slučaju upotrebljava samo množina, a jednina se može izvesti (singulativ), ali se ne upotrebljava. Primjeri kao što su očiloka, ušiluha, u kojima jednomu gramemu jednine odgavaraju dva gramema množine različita značenja, ali i različita roda, ili pak istoga roda, a samo različita značenja kao što su sati/ satovi, akti/aktovi, čini/činovi, prsteni/prstenovi, pojasi/pojasovi itd., nalaze se i u drugim jezicima, npr. u češkom kao i u hrvatskom oči i oka, uši i ucha; u talijanskom i bracci 'krakovi', le braccia 'ruke'; i membri 'članovi zajednice', le membra 'udovi'. Podtip čine primjeri kao što su listovi, grane, drva koji nasuprot drugomu množinskomu obliku (sati/satovi), koji su preuzeli svaki svoj dio značenja jedninskoga oblika, imaju paralelno zbirnu imenicu lišće, granje, drveće $e^{30}$ koja pripada tvorbi, a ne fleksiji. U tvorbi često motivirana riječ preuzima samo dio sadržaja motivirajuće riječi, a u ovom slučaju množina preuzima samo dio sadržaja jednine.

Množina se katkada može leksikalizirati, ali ona u takvim slučajevima nije drugi gramem kategorije broja, ne pripada fleksiji, nego pripada rječotvorju ${ }^{31}$ jer je leksikalizacijom nastala nova riječ. Leksikalizacija je množine jezična univerzalija, što ilustrira ovaj primjer: ${ }^{32}$

30 Imenica $d r v o$, ,morfološki se ponaša trojako: kao tvarna nebrojiva imenica $d r v o$ u značenju 'tvar' jest singulare tantum (kuća od drva), kao konkretna brojiva imenica drvo 'građa ili ogrjev dobiven obradom (obaranjem, sječom, rezanjem)', $\mathrm{N}$ mn. drva i zb. drvlje (staviti na vatru dva drva, dočekati zimu bez drvâ), kao konkretna brojiva imenica drvo 'stablo', 'biljni organizam' (rastu dva drveta), oblik za $\mathrm{N} \mathrm{mn}$. je drveta, ali se on ne upotrebljava, nego se upotrebljava zbirna imenica drveće" (Tafra 2000a: 77).

31 Rječotvorje obuhvaća sve načine nastanka nove riječi (Tafra i Košutar 2009), a tvorba je uži pojam i obuhvaća nastanak riječi pomoću morfema.

32 Marković (2012: 76) također navodi nekoliko primjera: starci 'roditelji', toplice 'terme', dvori 'kuća'. 
hrv. okovi 'željeza, negve', polj. żelaza, češ. pouta, rus кандаль, оковы, fr. chaînes, engl. irons, njem. Fesseln.

Premda hrvatski rječnici primjere kao što su okovi i izbori navode kao novo značenje koje ostvaruju samo množinski oblici, ne uspostavljaju novi rječnički članak, iako se dokaza da je posrijedi nova riječ može, među ostalim, naći i u jezicima u kojima nema podudaranja dvaju izraza, npr. fr. choix 'izbor', élections 'izbori'; španj. herrado 'okov', esposas 'okovi'; tal. catena 'okov', ceppi, 'okovi'. Graničnih slučajeva između fleksije i leksikalizacije svakako ima, ali u ovom je slučaju leksikalizacija ojačana ne samo istovrijednicama u drugim jezicima nego i terminologizacijom (izbori) te historizacijom (okovi za robove). Pomoću tih semantičkih procesa mogu se razumjeti i drugi neprototipni primjeri množine, npr. kisele kiše. Naziv je prošao leksikalizaciju množine i terminologizaciju jer ne postoji jednina: *kisela kiša.

Tako se množina pokazala u svoj svojoj raskoši gramatičke višeznačnosti. Jednina je manje zanimljiva jer se u opreci s množinom ostvaruju tek četiri tipa: protitipni (ormar - ormari), singularia tantum (ozon) i podtip, promjenjiv, s prijelazom iz singulare tantum u prototip (ulje) te singulativ (četinjača).

Često se kaže da imenice pluralia tantum mogu značiti 'jedno' i 'mnoštvo': roditelji jedan par i neodređeni broj parova, sanjke jedne i neodređeni broj. Ta su dva značenja logički nespojiva. ,Jedan te isti predmet ne može se pojaviti u količni od jednoga primjerka i u količini većoj od jednoga primjerka istodobno; događaj ne može biti istodobno završen i nezavršen i sl.” (Plungjan 2016: 98). U rečenici Na stolu su naočale glagolski je oblik obilježivač množine. Gramatički je to množina, a u stvarnosti ili je jedan predmet ili ih je više, oboje istodobno ne može biti. Dakle gramatičko se značenje broja toga oblika ne mora podudarati sa stvarnim brojem predmeta koje imenica označuje. Razumljivo je da većinom oblici imenice govore je li riječ o jednom predmetu ili o više njih: pročitala sam knjigu, pročitala sam knjige, ali se to može vidjeti i iz konteksta: s nosa su skliznule naočale, uvijek u torbi nosi nekoliko naočala.

Jednina se često upotrebljava mjesto množine, i obratno. Takva upotreba kategorije broja može imati različito značenje, često stilsko, ${ }^{33}$ ali i

33 Vince je uočio distributivnu upotrebu gramatičkoga broja zaključivši da se njome „mogu izraziti i posebne stilsko-izražajne nijanse" (1957). 
druga, nekoličinska značenja, npr. generičko (Na Medvednici raste kesten) i distributivno (Zastupnici su digli ruku za zakon; Injih dvojica objesiše puške na rame) ili pak služi za izricanje (ne)određenosti ${ }^{34}$. Nije rijetkost da se na pitanje Imaš li prijatelje odgovara: Ne, nemam prijatelje, iako bi bilo očekivano: Nemam prijatelja jer nema ni jednoga. Tako se množina upotrebljava, iako je riječ o jednom, gotovo pejorativno, pogotovo u razgovornom stilu: $h$ чему тебя только в университетах учили (Knjazev 2007: 89). Plungjan (u: Knjazev 2007: 90) smatra da se množinski oblik vremena upotrebljava u prvom redu s negativnim predznakom, a jednina s pozitivnim: teška vremena - dobro vrijeme. ${ }^{35}$ Da se jedninom ne izriče uvijek jednobroj, a množinom višebroj, davno je Isačenko (1961: 35) dokazao navevši ove primjere:

Подложить кирпич под калитку (денотат - единичный предмет)

Купить кирпич для постройки дачи (денотат - реальная множественность). ${ }^{36}$

Opsežna bi korpusna istraživanja otkrila bogatstvo neočekivanoga miješanja upotrebe jednine i množine. Upotreba jedninskih ili množinskih oblika uvelike ovisi o značenju imenice i o kategoriji brojivosti, o ustaljenosti kolokacijskih, terminoloških i frazeoloških sveza, ali i o komunikacijskoj situaciji u kojoj govornik ima mogućnost izricanja jednobroja ili višebroja. U tom je smislu kategorija broja manje ograničena obveznošću od kategorije roda i padeža. Stoga se kategorija broja treba opisivati i neovisno o kontekstu i u ovisnosti o kontekstu, što će dati njezinu složeniju sliku nego što se stječe dojam listajući hrvatske rječnike i gramatike.

\section{TERMINOLOŠKI I LEKSIKOGRAFSKI POGLED}

Spoznaje o kategoriji broja primjenjuju se u izradi rječnika jer se podaci o broju nalaze u većini, osobito u jednojezičnicima, ali i u uspostavi natuknica u jedninskom ili množinskom liku. Uzeto je nekoliko primjera većinom botaničkih i fizičkih naziva kojima nije valjano obrađen broj u rječnicima, s tim da izbor i naziva i rječnika služi tek za ilustraciju da se vidi u čem se griješi i da se potakne daljnje istraživanje, ali i ujednačenija gramatička obrada

\footnotetext{
34 Usp. J. Vince 2005.

35 Riznica (http://riznica.ihjj.hr/index.hr.html; pristupljeno 5.9.2018) ne pokazuje tu raspodjelu u hrvatskom jer s oba pridjeva ima i jedninske i množinske oblike, ali bi se za valjan zaključak morali vidjeti i drugi primjeri.

36 Staviti ciglu pod vrata (jedinični denotat). Kupiti ciglu za gradnju kuće (množinski denotat).
} 
naziva u rječnicima jer se oni veoma često otvaraju upravo radi traženja značenja naziva. Jezični priručnici obiluju primjerima imenica kojima se navodi potpuna paradigma broja, iako nisu brojive jer im njihovo značenje blokira množinu, ili obratno, blokira im jedninu, što je vrlo čest slučaj u nazivlju, osobito u taksonomiji. Stoga ne čudi kad se čuje da nadmorske visine iznose toliko i toliko metara ili da su jutros zabilježene ove temperature. Naime, na kategoriju broja djeluju određeni leksičko-semantički razredi pa gramatike redovito bilježe da su tvarne i apstraktne imenice singularia tantum. ${ }^{37}$ Jezikoslovci uz njih nabrajaju i druge, npr. Znika (2002: 125-126) dodaje vlastita imena, opće neapstraktne imenice koje izriču zbirnost i razne nazive koje je svrstala u tematske skupine. Međutim među općim imenicama našli su se nazivi (kornjaši, četinjače ...), među nazivima našla su se imena (Pluton, Mars, OPEC ...), ali nedostaju mnogi nazivi iz raznih područja, pogotovo iz botaničke i zoološke sistematike i drugih taksonomija u kojima je velik broj naziva ili pluralia tantum ili singularia tantum, što ćemo ilustrirati s nekoliko primjera. U općim i terminološkim rječnicima češće se sreću nazivi u kojih je neprepoznata pripadnost imenicama singularia tantum, ali ima i obratnih primjera koji bi se trebali navoditi u množini, a navedeni su u jednini.

Naime, viši taksoni redovito imaju množinski oblik pa su samo po obliku izjednačeni s imenicama pluralia tantum, ali se od njih razlikuju po tome što se od pluralia tantum ne mogu ni formalno tvoriti jedninski oblici, dok se od taksona može tvoriti jedninski oblik, tzv. singulativ, kad se želi izdvojiti predstavnik, ali se kao nazivi viših sistematskih jedinica upotrebljavaju uvijek u množini kao nebrojive imenice poput etnonima. Zato iznenađuju jedninski nazivi po našim rječnicima, i općim (ŠRHJ, VRH), i terminološkim, npr. četinjača i listača u Struni ${ }^{38}$ i Pojmovniku hrvatskoga drvnotehnološkog nazivalja (Jirouš-Rajković 2018), koji je rezultat projekta u Struni.

ŠRHJ nešto više posvećuje pažnje gramatičkoj obradi natuknica pa tako pored naziva znanstvenih disciplina (botanika, fonologija, morfologija...), bolesti (bruh, gripa ...), igara (nogomet ...) itd. nema množinskih oblika te

37 Ostalo je još dosta imeničnih skupina među kojima bi se našlo imenica koje nemaju potpunu paradigmu kategorije broja, npr. među posuđenicama, hipokoristicima, u nekim rječotvornim tipovima i sl.

38 http://struna.ihjj.hr/ Još više iznenađuje definicija: „vrsta drveća iz odjelka ...” jer je u biologiji vrsta osnovna sistematska jedinica, u ovom slučaju podređeni pojam. Vrste su među četinjačama, na primjer, obična smreka, alepski bor itd. 
se pretpostavlja da su te imenice singularia tantum, premda su te imenice trebale dobiti gramatičke odrednice jednako kao i pluralia tantum. Međutim, ostalo je još neprepoznate asimetričnosti kategorije broja, što dobro ilustrira obrada natuknice gramatika. Dva su značenja te natuknice, jedno je naziv, 'jezikoslovna grana', a drugo je metonimijsko, 'priručnik'. Samo u tom drugom značenju imenica ima potpunu paradigmu kategorije broja. Inače taj rječnik uz više natuknica stavlja množinske oblike, iako one pripadaju skupini singularia tantum, pri čem ima i nedosljednosti, npr. uz daltonizam ne stoje množinski oblici, a uz botulizam stoje. Posebno se griješi u obradi višeznačnica u kojih su pojedino značenje i kategorija broja u međusobnoj ovisnosti. Tako su imenice tipa višnja, trešnja, dunja obrađene kao brojive, a one kao botanički nazivi vrsta voćaka nemaju množinu, ali ju imaju u drugom, metonimijskom značenju 'plod tih voćaka'. To je velika skupina višeznačnih imenica koja ima i potpunu i nepotpunu paradigmu ovisno o značenju, što je ostalo neprepoznato u rječnicima.

U botaničkoj terminologiji vrlo je očita asimetričnost kategorije broja, što se zorno vidi na primjeru imenice bukva (Tafra 2005: 173). U terminološkim značenjima ta je imenica ili singulare tantum (vrsta Fagus sylvatica i rod Fagus) ili plurale tantum (porodica Fagacaeae). U značenju 'tvar' (bukovina) također je singulare tantum. Potpunu paradigmu imenica bukva ima u značenju 'stablo iz toga roda' i u prenesenom značenju 'glupan'. VRH je samo djelomično ispravno stavljao odrednice za množinu uz značenje 'biljna porodica' (s. v. bukva, ruža itd.), ali ne i odrednicu za jedninu u značenju 'rod'. Svaka je sistematska jedinica, bila vrsta, rod, porodica ili koja druga, samo jedna te naziv za nju ne može biti brojiva imenica. Ako definicija nije terminološka i ako nema terminološku odrednicu, imenica pripada općemu jeziku i u općem jeziku postaje brojiva (ruža, mačka, visina, temperatura ...). Sve to ne mora znati botaničar ili drugi stručnjak, ali bi jezikoslovac to trebao znati, što se u rječnicima, nažalost, ne vidi. Stoga se redovito u praksi upotrebljavaju množinski oblici hrastovi kad se govori o različitim vrstama hrasta (rod Qercus). Leksikografi nisu uočili ni razliku u ostvarivanju gramema kategorije broja u skupini naziva povrća i jela od njega, npr. od više značenja riječi krumpir izdvojimo tri. Kao botanički naziv za vrstu zeljaste biljke (Solanum tuberosum) i kao naziv za jelo (Najeo se krumpira za ručak) ima samo jedninu, a tek kao naziv za gomolj ima i množinu (U loncu je pet krumpira).

Neprepoznati su također nazivi za mjerne veličine kao singularia tantum. Naime, mjerna je veličina „svojstvo pojave, tijela ili tvari koja se može 
kakvoćno razlikovati i velikoćno odrediti" (Brezinšćak 2005: 81). Iz te se definicije vidi da je riječ o apstraktnom pojmu koji kao takav nije razlučiv pa ni imenica ne može biti brojiva. Stoga se mjeri duljina, vrijeme, masa, obujam, tlak, sila, nadmorska visina itd. te su u ovim rečenicama trebali biti jedninski oblici podvučenih naziva: ${ }^{39}$

Utvrđena je signifikantna razlika između obujama tovara.

S dubinom su se razlike temperatura tla pravilno smanjivale.

Prsni su promjeri istraživanih stabala bili od 25 do $47 \mathrm{~cm}$, a visine stabala od 17 do $29 \mathrm{~m}$.

Kretanja razina podzemnih voda do dubina od pola metra ...

Utrošak vremena vožnje izračunat je na temelju prosječnih brzina.

Stanje u hrvatskoj leksikografiji dobro ilustrira ŠRHJ koji su radili vrsni kroatisti pa bi se očekivalo da će gramatički podaci o natuknicama biti točni i ujednačeni. Na primjer, uz natuknice masa, obujam, brzina, tlak, napon, otpor, snaga, koje su definirane kao matematički ili fizički nazivi, stoji množinski oblik. Meteorološki su nazivi pak nejednako obrađeni; kiša, mraz, rosa, temperatura, oborina imaju potpunu paradigmu kategorije broja, a tuča, grad i vlaga nemaju pa su valjda singularia tantum, iako nemaju odrednice. ${ }^{40}$ Ako uz natuknicu oborina stoji terminološka odrednica, a definicija glasi: „,voda u tekućemu ili čvrstomu stanju koja iz oblaka pada na površinu Zemlje...", ta je imenica već time određena kao singulare tantum (voda u definiciji kao tvar također) pa su u gramatičkom bloku suvišni množinski oblici. Imenice kojima se imenuju prirodne pojave ne mogu imati množinu jer su u tom značenju nebrojive, ne označuju istovrsne entitete odvojive jedan od drugoga (*pet mrazova, ${ }^{*}$ pet temperatura ...), ali u neterminološkom značenju mogu, no tada označuju tu pojavu vremenski, prostorno, količinski ili kakvoćno određenu (snjegovi, kiše, vode...).

Govornik hrvatskoga jezika ne mora znati pravila o upotrebi jedninskih i množinskih oblika neke imenice, ali bi kroatisti u rječnicima, pogotovo onim normativnim, a školski je rječnik normativan već po definiciji jer je namijenjen školama, trebali dati osnovne gramatičke i značenjske podatke o natuknici. Ako školska gramatika propisuje da tvarne (zovu ih i gradivne) imenice nemaju množinske oblike, tada uz natuknice tipa kruh, mast, vino ne bi smjeli stajati u gramatičkom bloku oblici za nominativ i genitiv mno-

39 Primjeri iz lektorske prakse.

40 U popisu kratica nema sg. t., ali ima kratica pl.t. kojom su obilježene natuknice koje pripadaju toj imeničnoj skupini. U predgovoru nema objašnjenja te nedosljednosti. 
žine koje daje ŠRHJ. Prema definiciji (,alkoholno piće dobiveno vrenjem grožđanoga soka i daljnjim posebnim postupcima" ${ }^{41}$ ) vino i druge imenice iz te skupine jesu tvarne imenice pa prema tomu u svom primarnom značenju pripadaju imenicama singularia tantum. No ŠRHJ ima uz sintagme bijelo vino, crno vino i sintagmu dalmatinska vina, ali u toj se sintagmi ostvaruje značenje 'vrsta toga pića prema zemljopisnomu porijeklu', što je trebalo navesti kao drugo značenje. U Rječniku hrvatskoga jezika (Šonje 2000) natuknica vrijeme obrađena je u sedam značenja. U gramatičkom su bloku dani oblici za nominativ i genitiv množine, ali množinu ta riječ zasigurno nema kao fizički i meteorološki naziv (mjeriti vrijeme, astronomsko vrijeme, prognoza vremena itd.) za razliku od značenja 'prilike' (teška vremena, dobra stara vremena). Takvih primjera ima dosta. Nažalost, iako je STRUNA zamišljena kao terminološka baza usustavljenoga nazivlja, na njezinoj je stranici $^{42}$ vidljivo da njezinom koncepcijom nije predviđeno davanje gramatičkih podataka osim odrednica za vrstu riječi te uobičajene odrednice za rod i broj kod imenica. Budući da nema primjera upotrebe, uporabnik neće znati upotrebljava li se visina (i mnogi drugi nazivi) kao matematički naziv i u množini. Još će veći problem imati s nazivima snijeg, vrijeme, snaga, mraz jer će mu trebati i drugi jezični priručnici, ali ni nakon zaglédanja u njih neće dobiti ispravne podatke. Mana je hrvatskih rječnika što gramatičke podatke o natuknici daju redovito u glavi rječničkoga članka, a ne uz pojedina značenja ako je natuknica i gramatički višeznačna ${ }^{43}$ pa se njezina gramatička obilježja razlikuju u ovisnosti o pojedinom leksičkom značenju.

Hrvatski rječnici ne prepoznaju uvijek imenice singularia i pluralia tantum i prijelaze iz nebrojivih u brojive u pojedinim značenjima, a pogotovo ne prepoznaju leksikalizirane množinske oblike. Rječnik ne treba bilježiti pojedinačnu stilski obilježenu upotrebu jednine u značenju višebroja, i obratno, ali treba uz imenice singularia tantum staviti njihovu gramatičku odrednicu, a ako imenica u nekom značenju prelazi iz nebrojive u brojivu, onda odrednicu sg. $t$. treba staviti samo uz primarno, a ne u glavi rječničkoga članka pa da se odnosi i na metaforička i metonimijska značenja u kojima imenica ima oba gramema.

${ }^{41}$ Definicija je, inače, netočna jer se vino ne dobiva samo od grožđa.

42 http://struna.ihjj.hr/

43 O gramatičkoj višeznačnosti usp. Tafra 2017. 


\section{ZAKLJUČAK}

Kategorija je broja važna za razumijevanje morfološke strukture imenica, ali je važna i za razumijevanje sročnosnih razreda. $U$ oba slučaja ima razredbenu ulogu. Prema tomu u gramatikama se kategorija broja treba opisivati na dvjema razinama, na morfološkoj kao popis oblika, zajedno s kategorijom roda (Tafra 2007), a na sintaktičkoj se razini trebaju dati pravila o upotrebi jedninskih i množinskih oblika. Pritom uvijek treba imati na umu i semantičke kategorije jer o njima ovisi ima li imenica potpunu ili nepotpunu paradigmu kategorije broja. U rječnicima pak uz imenice koje imaju punu paradigmu kategorije broja ne treba stajati po uzoru na engleske rječnike podatak da je imenica brojiva jer se u hrvatskom jeziku brojivost, kao i određenost, utvrđuje u kontekstu. Ako pak imenica ima nepotpunu paradigmu, tada treba staviti gramatičku odrednicu (kraticu) sg. t. ili pl. t. Ako pak imenica singulare tantum u nekom svom sekundarnom značenju postaje brojiva jer se njezino značenje prostorno, vremenski ili situacijski omeđilo, konkretiziralo, opredmetilo, tada uz to značenje treba staviti množinski oblik koji je predviđen koncepcijom rječnika (N mn., G mn. ...). Množinski se oblik ne bi trebao naći u glavi rječničkoga članka ako je imenica u svom primarnom značenju singulare tantum. Viši taksoni koji se upotrebljavaju samo u množini trebaju imati množinsku natuknicu. Tada leksikografi neće morati stavljati drugo značenje ,pripadnica istoimene skupine” (ŠRHJ s. v. četinjača) jer se razumijeva da naziv imenuje i jedinku, ako imenuje skupinu tih jedinki. Terminološki bi pak rječnici osobito trebali voditi računa o kategoriji broja jer su mnogi nazivi ili singularia tantum ili pluralia tantum.

Među zaključcima valja izdvojiti nazivoslovni prijedlog da se nepotpuna paradigma kategorije broja imenuje nultom paradigmom umjesto defektiva te asimetričnost kategorije broja umjesto defektivnosti. Ostvaraji su kategorije broja jednina i množina koji su na emskoj razini gramatičke jedinice - gramemi. Izraz gramema su nastavci, a sadržaj su - jednobroj i višebroj, nazivi koji se ovdje predlažu.

$\mathrm{U}$ istraživanju gramatičke semantike kategorije broja primijenjene su metode leksičke semantike pa je tako bilo olakšano otkrivanje gramatičke višeznačnosti kategorije broja i morfosintaktičkih tipova jednine i množine. Iako je u radu bilo riječi o asimetričnosti paradigmi kategorije broja, uočena je i asimetričnost izraza i sadržaja dvaju gramema kategorije broja pa bi se u tom smjeru trebalo dalje krenuti te na osnovi korpusnih istraživanja upotrebe kategorije broja doći do tipologije upravo asimetričnosti izraza i 
sadržaja jednako kao što se već odavno u opisu vremena u glagola zna da, primjerice, prezentski oblik može imati značenje budućnosti ili prošlosti. Primjenom različitih kriterija i metoda u proučavanju kategorije broja dobit će se njezina složenija slika nego što ju daju hrvatske gramatike i rječnici.

\section{LITERATURA}

Anić, Vladimir. 1998. Rječnik hrvatskoga jezika. Zagreb: Novi Liber.

Babić, Stjepan, i sur. 1991. Povijesni pregled, glasovi i oblici hrvatskoga književnog jezika : Nacrti za gramatiku. Zagreb: HAZU.

Barić, Eugenija, i sur. 1995. Hrvatska gramatika. Zagreb: Školska knjiga.

Belaj, Branimir; Tanacković Faletar, Goran. 2014. Kognitivna gramatika hrvatskoga jezika. Knjiga prva: Imenska sintagma i sintaksa padeža. Zagreb: Disput.

Brezinšćak, Marijan. 2005. Temeljna mjerenja mase. Zagreb: Hrvatsko mjeriteljsko društvo.

Corbet, Greville G. 2000. Number. Cambridge: Cambridge University Press.

Gortan-Premk 1997: Даринка Гортан-Премк. Полисемија и организаиија лексичког система у српскоме језику. Београд: Институт за српски језик САНУ.

Hudeček, Lana; Mihaljević, Milica. 2017. Hrvatska školska gramatika. Zagreb: Institut za hrvatski jezik i jezikoslovlje.

Isačenko 1961: А. В. Исаченко. 1961. О грамматическом значении. Вопросы языкознания, 1, 28-43.

Jirouš-Rajković, Vlatka [glav. ur.]. 2018. Pojmovnik hrvatskoga drvnotehnološkog nazivalja. Zagreb: Šumarski fakultet Sveučilišta u Zagrebu; Institut za hrvatski jezik i jezikoslovlje.

Knjazev 2007: Ю. П. Князев, 2007. Грамматическая семантика. Москва: Языки славянских культур.

Marković, Ivan, 2012. Uvod u jezičnu morfologiju. Zagreb: Disput.

Peti, Mirko, 2001. Zbrojina. Rasprave Instituta za hrvatski jezik i jezikoslovlje, 27, 209-250.

Peti, Mirko, 2004. Oblici nebrojivosti u hrvatskom jeziku. Zagreb: Institut za hrvatski jezik i jezikoslovlje.

Pišković, Tatjana. 2011. Gramatika roda. Zagreb: Disput.

Plungjan, Vladimir A. 2016. Opća morfologija i gramatička semantika [preveo Petar Vuković]. Zagreb: Srednja Europa.

Pranjković, Ivo. 1984. Zbirne imenice i kategorija broja u hrvatskom i srpskom jeziku. Rod i broj u srpskohrvatskom jeziku. Naučni sastanak slavista u Vukove dane: Referati i saopštenja, 13/1. Beograd: Međunarodni slavistički centar.

Pranjković, Ivo. 2013. Gramatička značenja. Zagreb: Matica hrvatska. 
Šonje, Jure [ur.]. 2000. Rječnik hrvatskoga jezika. Zagreb: Leksikografski zavod; Školska knjiga.

Ruska gramatika: Краткая русская грамматика под ред. Н. Ю. Шведовой и В. В. Лопатины. 2002. Москва: Российская академия наук, Институт русского языка В. В. Виноградова.

Silić, Josip; Pranjković, Ivo. 2005. Gramatika hrvatskoga jezika. Zagreb: Školska knjiga.

Šarić, Ljiljana. 2002. Kvantifikacija u hrvatskome jeziku. Zagreb: Institut za hrvatski jezik i jezikoslovlje.

ŠRHJ: Dunja Brozović Rončević [glav. ur.]. 2012. Školski rječnik hrvatskoga jezika. Zagreb: Institut za hrvatski jezik i jezikoslovlje; Školska knjiga.

Tafra, Branka. 2000a. „Nepravilnici” u hrvatskoj gramatici i rječniku. U: Tafra 2005, 67-82.

Tafra, Branka. 2000b. Leksičko značenje i gramatička kategorija broja. U: Tafra 2005, 125-136.

Tafra, Branka. 2002. Jezikoslovac Šime Starčević. U: Shime Starcsevich. Nòvà ricsôslovica iliricska, pretisak. Zagreb: Institut za hrvatski jezik i jezikoslovlje.

Tafra, Branka. 2004. Dopune hrvatskoj gramatici. „Jezik”, 51, 5, 169-176.

Tafra, Branka. 2005. Od riječi do rječnika. Zagreb: Školska knjiga.

Tafra, Branka. 2007. Broj i rod ispočetka. „Filologija”, 49, 211-233.

Tafra, Branka. 2017. Gramatička polisemija. U: Путевима речи, Зборник радова у част Даринки Гортан Премк [ур. Рајна Драгићевић]. Београд: Филолошки факултет Универзитета у Београду. 563-575.

Tafra, Branka; Košutar, Petra. 2009. Rječotvorni modeli u hrvatskom jeziku. „Suvremena lingvistika", 67, 1, 87-107.

Vince, Jasna. 2005. Izražavanje neodređenosti množinom. U: Hrvatsko-bugarski odnosi u 19. i 20. stoljeću [ur. Josip Bratulić]. Zagreb: Hrvatsko-bugarsko društvo. 351-357.

Vince, Zlatko. 1957. Distributivna upotreba gramatičkog broja. „Jezik”, 6, 3, 78-85.

VRH: Ljiljana Jojić [glav. ur.]. 2015. Veliki rječnik hrvatskoga standardnog jezika. Zagreb: Školska knjiga.

Znika, Marija. 2002. Kategorija brojivosti u hrvatskom jeziku. Zagreb: Institut za hrvatski jezik i jezikoslovlje. 


\section{SUMMARY \\ GRAMMATICAL AMBIGUITY OF THE CATEGORY OF NUMBER}

The focus of this paper is on the grammatical ambiguity of the category of number, determining its basic types, and detecting the assymetry of its grammemes, especially in terminology, which has not been observed and appropriately described in Croatian language manuals. Since the relationship between the category of countability of nouns and the category of number is tightly intertwined and cannot be completely circumvented, it will be discussed with reference to the Croatian literature and some controversial opinions. Several additions to the terminology will be proposed as well as in interpreting the category of number in order to improve not only grammatical descriptions but also the grammatical treatment of dictionary entries, which clearly reflect the inseparability of grammar and semantics precisely by using the example of the category of number.

Keywords: grammar, semantics, number, singular, plural 